diagnostic features of 60 consecutive cases. Mayo Clin Proc 1976;51: 417-29.

2 Turner RC, Harris E. Diagnosis of insulinomas by suppression tests. Lancet 1974 ;ii:188-90.

${ }^{3}$ Marks V. The investigation of hypoglycaemia. Br $\mathcal{F}$ Hosp Med 1974;11 : 731-43.

4 Turner RC, Oakley NW, Nabarro JDN. Control of basal insulin secretion, with special reference to the diagnosis of insulinomas. $\mathrm{Br} \mathrm{Med} \mathcal{F} 1971$; ii: $132-5$.

${ }^{5}$ Fajans SS, Schneider JM, Schteingart DE, Conn JW. The diagnostic value of sodium tolbutamide in hypoglycaemic states. $\mathcal{f}$ Clin Endocrinol Metab $1961 ; 21: 371-86$.

6 Marks V, Samols E. Glucagon test for insulinoma: a chemical study in 25 cases. F Clin Pathol $1968 ; 21: 346-52$.

7 Rubenstein AH, Block MB, Starr J, Steiner DF. Proinsulin and C-peptide in blood. Diabetes 1972;21, suppl 2:661-72.

${ }^{8}$ Stellon A, Townell NH. C-peptide assay for factitious hyperinsulinism. Lancet 1979 ;ii:148-9.

- Sved S, McGilveray IJ, Beadoin N. Assay of sulfonylureas in human plasma by high-performance liquid chromatography. F Pharm Sci 1976; 65 :1356-9.

10 Robins JM, Bookstein JJ, Oberman HA, Fajans SS. Selective angiography in localizing islet-cell tumours of the pancreas. A further appraisal. Radiology 1973;106:525-8.

11 Gray RK, Rösch J, Grollman JH. Arteriography in the diagnosis of isletcell tumours. Radiology 1970;97:39-44.

12 Le Quesne LP, Nabarro JDN, Kurtz A, Zweig A. The management of insulin tumours of the pancreas. Brf Surg 1979;66:373-8.

${ }^{13}$ Ingemansson S, Lunderquist A, Lundquist I, Lövdahl R, Tibblin S. Portal and pancreatic vein catheterization with radioimmunologic determination of insulin. Surg Gynecol Obstet 1975;141:705-11.

14 Turner RC, Morris PJ, Lee ECG, Harris EA, Dick R. Localisation of insulinomas. Lancet $1978 ; \mathrm{i}: 515-8$.

15 Pedrazzoli S, Feltrin G, Dodi G, Miotto D, Pasquali C, Cevese PG. Usefulness of transhepatic portal catheterization in the treatment of insulinomas. Br $\mathcal{F}$ Surg 1980;67:557-61.

16 Daggett PR, Goodburn AE, Kurtz AB, Le Quesne LP, Nabarro JDN, Raphael MJ. Is pre-operative localization of insulinomas necessary? Lancet 1981 ; $\mathrm{i}: 483-6$.

17 Marks V, Samols E. Diazoxide therapy of intractable hypoglycaemia. Ann NY Acad Sci 1968;150:442-54.

18 Mengoli L, Le Quesne LP. Blind pancreatic resection for suspected insulinoma: a review of the problem. Br F Surg 1967;54:749-56.

19 Herbai G, Lundin A. Treatment of malignant metastatic pancreatic insulinoma with streptozotocin. Review of 21 cases described in detail in the literature and report of complete remission of a new case. Acta Med Scand 1976;200:447-52.

\section{Disability in the developing world}

In the year of the disabled, what is the outlook for those with mental and physical handicaps in the developing world? In most of its countries cities are growing rapidly as they continually spawn fresh slums, but two-thirds of the population still live in rural areas, and two-fifths are likely to be under 15 years old. The developing countries can spend very little per head of population on health and what they spend is divided most unequally between the rural and urban populations. For example, the Maharashtra State Commission, India, calculated that its yearly expenditure on health was $\$ 1.60$ per person, but $80 \%$ of this sum was spent in three cities and only $4 \%$ was available for the large population of the rural villages-an annual expenditure of only $\$ 0.02$ per head.

This inequitable division of resources has arisen largely through the emphasis placed on large hospitals and on curative care, but even the relatively new science of rehabilitation has unfortunately become heavily associated with technology. The World Health Organisation now recognises 14 separate professions offering different "therapies." In developing countries rehabilitation centres have been set up within or close to the teaching and other large hospitals, so that treatment is in effect reserved for the local élite who attend these "disease palaces."

Just as a swing has begun away from the high-cost care in large hospitals towards primary health care, so in the rehabilita- $\overline{\widehat{C}}$ tion sciences should the developing world consider needs at the level of primary care. If each country set an objective of one generalist rehabilitation worker for each district of 50-100 000 \% population at least some limited services would become widely $\varrho$ available. Such an individual would need a wide training in rehabilitation skills, giving him the knowledge to cope with most (but not all) the problems presenting in any one rehabilitation discipline. Much of his time would be spent training mothers, village part-time health workers, clinic nurses, and medical assistants in the detection of early disability. He would not have time to provide day-to-day treatment for children, but would instead educate parents and older siblings on how to provide care and rehabilitation within the home.

Such a programme may be resisted by the existing rehabilitation professionals, currently struggling to maintain their positions in the teaching and large hospitals. They will not welcome suggestions that in 1981 they might dilute their o profession and work at primary level in the villages. The International Year of Disabled Persons should, however, io provide an impetus for volunteers from industrialised countries $\infty$ to offer their services. Such volunteers could be attached to 은

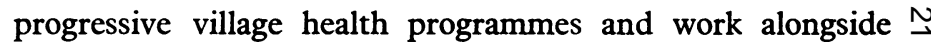
part-time health workers and those who train them. With $\overline{3}$ others in the health team they would seek to identify functional impairment through simple developmental screening tests for the young child. Older children could be assessed on $\oplus$ the basis of their progress up the normal ladder of increasing responsibility. In this way the rehabilitation worker would no longer depend on referrals from conventionally trained medical staff.

The experience of overseas volunteers would help countries evolve a training programme for generalists to organise rehabilitation at a district level. Such volunteers must expect frustration, and those trained in depth in only one specialty would have particular difficulty. Volunteers with training in physiotherapy, for example, would have to meet and learn to help patients with speech defects or with problems arising from educational subnormality. They would also be frustrated by the lack of resources in the rural areas and their inability to find time for management in depth of the problems for which they had been specifically trained.

All societies and families have evolved methods of coping with and reacting to disabled persons in their community. When the methods are appropriate they need to be retained and developed and information spread through the local communications network. Clearly such solutions would have to be feasible within the resources of the family and the community.

Those directing volunteer programmes can send out individuals only in response to requests. At present few of those concerned in developing village health programmes have $\stackrel{?}{?}$ appreciated the part that therapists might play in furthering and promoting the health of the community. Of all the health sciences, rehabilitation may be the most labour intensive, and much of the labour can come from within the extended family-a solution particularly appropriate for the Third World. 